\title{
HSP90 and its inhibitors (Review)
}

\author{
HUIFANG HAO $^{1}$, YOSHIO NAOMOTO ${ }^{1}$, XIAOHONG BAO $^{1}$, NOBUYUKI WATANABE ${ }^{1}$, \\ KAZUFUMI SAKURAMA ${ }^{1}$, KAZUHIRO NOMA ${ }^{1}$, TAKAYUKI MOTOKI ${ }^{1}$, YASUKO TOMONO ${ }^{2}$, \\ TAKUYA FUKAZAWA ${ }^{1}$, YASUHIRO SHIRAKAWA ${ }^{1}$, TOMOKI YAMATSUJI ${ }^{1}$, \\ JUNJI MATSUOKA $^{1}$ and MUNENORI TAKAOKA ${ }^{1}$
}

\begin{abstract}
${ }^{1}$ Department of Gastroenterological Surgery, Transplant and Surgical Oncology, Graduate School of Medicine, Dentistry and Pharmaceutical Sciences, Okayama University; ${ }^{2}$ Shigei Medical Research Institute, Okayama, Japan
\end{abstract}

Received January 4, 2010; Accepted March 2, 2010

DOI: 10.3892/or_00000787

\begin{abstract}
The HSP90 molecular chaperone family is highly conserved and expressed in various organisms ranging from prokaryotes to eukaryotes. HSP90 proteins play essential housekeeping functions, such as controlling the activity, turnover and trafficking of various proteins, promoting cell survival through maintaining the structural and functional integrity of some client proteins which control cell survival, proliferation and apoptosis, and play an important role in the progression of malignant disease. HSP90 proteins are ATPdependent chaperones and the binding and hydrolysis of ATP are coupled to conformation changes of HSP90, which facilitate client protein folding and maturation. Many natural and synthetic molecular compounds have been proposed as promising cancer therapy via disrupting the formation of complex ATP-HSP90-client proteins.
\end{abstract}

\section{Contents}

1. Introduction

2. Structure and function

3. HSP90 inhibitors

4. Conclusions

Correspondence to: Dr Yoshio Naomoto, Department of Gastroenterological Surgery, Transplant and Surgical Oncology, Graduate School of Medicine, Dentistry and Pharmaceutical Sciences, Okayama University, 2-5-1 Shikata-cho, Okayama 700-8558, Japan

E-mail: ynaomoto@md.okayama-u.ac.jp

Abbreviations: HSP90, heat shock proteins; GA, geldanamycin; 17-AAG, 17-(allylamino)-17-demethoxy geldanamycin; 17-DMAG, 17-dimethylaminoethylamino-17-demethoxygeldanamycin hydrochloride; GIST, gastrointestinal stromal tumour; SAR, structureactivity relationships; (-)-EGCG, (-)-epigallocatechin-3-gallate

Key words: heat shock protein 90, chaperone, inhibitors

\section{Introduction}

The HSP90 molecular chaperone family is highly conserved and expressed in various organisms ranging from prokaryotes to eukaryotes and even under normal conditions HSP90 proteins account for $1-2 \%$ of all cellular proteins in most cells (1). The expression of HSP90 is elevated up to 10 -fold when exposed to physiologic stress including heat, heavy metals, hypoxia and low $\mathrm{pH}(2,3)$. HSP90 proteins play essential housekeeping functions, such as controlling the activity, turnover and trafficking of various proteins, promoting cell survival through maintaining the structural and functional integrity of some client proteins which control cell survival, proliferation and apoptosis $(4,5)$. Many reports have indicated that HSP90 proteins play an important role in the progression of malignant disease and HSP90 expression is 2- to 10-fold higher in tumor cells than in normal cells (6-8). HSP90 sustains cancer cells through interacting smoothly with client substrates which contain kinases, hormone receptors and transcription factors directly involved in evoking multi-step malignancies, and also with mutated oncogenic proteins necessary for transformed phenotype (9). Therefore, HSP90 has been proposed as a promising target for therapy of various human cancers.

\section{Structure and function}

Researchers indicated that the HSP90 molecular chaperone family is present in the cytosol, nucleoplasm, endoplasmic reticulum (ER), mitochondria and chloroplasts $(1,10,11)$. Members of the human HSP90 chaperone family are listed in Table I. There are four kinds of isoforms, including HSP $90 \alpha$ (90 kDa heat-shock protein), HSP90ß, Grp94 (94 kDa glucose-regulated protein) and TRAP1 (tumor necrosis factor receptor-associated protein 1) $(1,12-14)$. HSP90 $\alpha$ and HSP90ß are cytosolic proteins and share $76 \%$ homology due to gene duplication during evolution $(1,15)$. Mainly Grp94 resides in the endoplasmic reticulum (ER), while TRAP1 is a mitochondrial paralogue and connected with Eubacterial HtpG $(14,16,17)$. In addition, a novel member of the HSP90 family called HSP90N was reported to be related with neoplastic transformation (18). 
Table I. Human HSP90 chaperone family.

\begin{tabular}{lllc}
\hline Protein & Subcellular location & Gene & Gene chromosomal localization \\
\hline HSP90 $\alpha$ & Cytosolic & HSP90AA & Chromosomes 1,3,4,11,14 \\
HSP90ß & Cytosolic & HSP90AB & Chromosomes 3,4,6,13,15 \\
Grp94 & Endoplasmic reticulum & HSP90B & Chromosomes 1,12,15 \\
TNF receptor-associated protein & Mitochondria & TRAP & Chromosome 16 \\
\hline
\end{tabular}

The crystal structures of HSP90 proteins from Escherichia coli, yeast and human have shown that the basic domain is conserved, although it become more complex with multifunction from procaryote to eukaryote (19-24). Hsp90 chaperones exist as obligate homodimers, with each identical subunit comprised of an $\mathrm{N}$-terminal domain, a middle domain, a non-conserved charged middle linker region which connects the N-terminal domain with the middle domain, and a $\mathrm{C}$ terminal domain (19-24). There are two ATP binding sites, one is on the $\mathrm{N}$-terminus and the other is on the C-terminus (25). The C-terminal domain contains a calmodulin binding site and dimerization site associating with its partner domain in the corresponding subunit to form dimer $(1,18,26,27)$. A conserved pentapeptide sequence (MEEVD) lies in the extended C-terminal end of the eucaryotic protein, which serves as the primary binding site for tetratricopeptide repeat (TRP-a 34 amino acid sequence specifically binding to HSP90) domain containing co-chaperones (28-30). The middle domin of HSP90 exhibits a high affinity for co-chaperones and client proteins and seems to discriminate between different substrate types and to adjust the molecular chaperone for the proper substrate activation (31-35).

The crystallization and three-dimensional structure analysis of the $\mathrm{N}$-terminal domain is a milestone in the scientific exploration of the HSP90 molecular chaperone family $(21,23,36)$. Subsequently, the crystal structure of the HSP90geldanamycin binding domain was reported to be a pocket which is also a likely binding site for the polypeptide substrate. So geldanamycin inhibits the HSP-catalyzed conformational reaction of these substrates via binding to the pocket (23). Another researcher group reported a different complex of crystal structures between the N-terminal domain of the yeast HSP90 chaperone and ADP/ATP comprised of a specific adenine nucleotide binding site homologous to the ATPbinding site of DNA, suggesting that geldanamycin works by blocking the binding of nucleotides to Hsp90 (21). A similar model was proposed in which the HSP90-geldanamycin binding domain is an ATP/ADP switch domain that regulates HSP90 conformation and the GA binding to HSP90 locks the chaperone into its ADP-dependent configuration (37). In subsequent years, it was established that Hsp90 is an ATPdependent chaperone and the binding and hydrolysis of ATP are coupled to conformation changes of HSP90, which facilitate client protein folding and maturation and are disrupted by geldanamycin (38-42).

In recent years, more complex and detailed mechanisms of the ATP-driven chaperone cycle of HSP90 have been intensively explored. A crystal structure of complex with full length yeast HSP90 and an ATP analogue directly confirms that the $\mathrm{N}$-terminal dimerization is necessary for the ATP hydrolysis which accompanies conformation change of client proteins (22). They further indicated that upon the ATPbound state, the N-terminus and lid segment (residues 94125 ) of the $\mathrm{N}$ domain and the catalytic loop of the middle segment together act as conformational switches to position the two halves of the catalytic apparatus for ATP hydrolysis (22). At the same time Buchner et al (2) proposed a model to explain how ATP hydrolysis is regulated and linked to conformational changes which is consistent with the crystal structure of full length yeast HSP90 and ATP. i) The stable structure of the first 24 amino acids and the lid region within the $\mathrm{N}$ terminal domain preclude $\mathrm{N}$-terminal dimerization; ii) upon binding of the ATP, this stable structure is opened, the dimerization site becomes accessible, and the N-terminal strands are exchanged with corresponding monomeric subunit to form the ATPase-active state; iii) after N-terminal dimerization, the positioning of the ATP-lid in its new orientation is required for the ATP-hydrolyzing reaction in this domain; iv) the association of the $\mathrm{N}$-terminal domain with the middle domain of HSP90 is necessary for efficient hydrolysis (43).

Shiau et al further proposed a unified structurally validated mechanism model linking HSP90 ATPase activity and client protein binding and release. They indicated that a distinct set of lid segment conformation is responsible for coupling the nucleotide binding and hydrolysis to a cycle of domain rearrangements, which in turn regulate client-protein binding and release (19). i) Without the binding of ATP, HSP90 presents multiple hydrophobic elements into the central cleft, containing the hydrophobic patch formed by one face of the lid segment which in an inactive state as well as helix H1. The most hydrophobic surface area of the central cleft is supposed to be the most optimal for client-protein binding. ii) The ATP binding drives lid rearrangement and reorientation of the N-terminal domain and the middle domain, to which client proteins could be bound in the central cavity in this ATP-containing intermediate state of HSP90. iii) After rearrangement, the lid stabilizes $\mathrm{N}$-terminal domain dimerization via interaction with $\mathrm{N}$-terminal domain residues of the partner protomer and this ATP-mediated closing of the interprotomer space could very well drive client-protein remodeling. iv) With the dimerization of the $\mathrm{N}$-terminal domain of subunits, the ATP hydrolysis occurs and the lid changes conformation accordingly, this new lid conformation allows the interdigitation of the lid, the src loop, and the CTD 
$\mathrm{H} 21$, mutually masking their otherwise exposed hydrophobic core, and finally assures complete release of client proteins from HSP90 (19).

\section{HSP90 inhibitors}

Considering the extremely important function of HSP90 in organisms, especially in the occurrence and development of various tumors, targeting HSP90 is considered to have bright future. Through knowledge of the ATP-driven chaperone cycle of Hsp90, it might be possible to identify and design small molecule compounds which selectively affect the different stages of the cycle, thus providing more selective and effective therapeutics. In fact the exploring function of HSP90 is accompanied by the development of small inhibitors targeting HSP90, so far many kinds of HSP90 inhibitors have been identified which are listed in Table II and many of them have already exhibited good antitumor effects and have entered into clinical trials. The following will introduce the various kinds of natural and synthetic HSP90 inhibitors.

Geldanamycin. Geldanamycin (GA) is a kind of benzoquinone ansamycin antibiotic. As early as 1994, researchers proposed the ability of GA to revert the transformed phenotype of V-src-transformed cells via binding to HSP90 and disrupting its chaperone function (44). Subsequently, the identification of the ADP/ATP binding site in the N-terminal of HSP90 has driven the understanding of the inhibition mechanism of GA for cancer cells $(21,23,36)$. GA competitively binds to the N-terminal ATP binding site of HSP90, which prevents ATP binding and disrupts the ATP-dependent conformational cycling reactions of a wide range of client proteins involved in signal transduction, cell cycle regulation and hormone responsiveness $(21,23,38)$. Although GA exhibits potent antitumor effects, it also showed high hepatotoxicity and poor solubility in preclinical studies in animals, which has driven the development of geldanamycin analogues (45). One possible reason of the toxicity is the C-17 methoxy group, which is reactive toward nucleophiles usually present in biological molecules. Replacement of the methoxy moiety at $\mathrm{C}-17$ of GA with alkylamino groups are less reactive to nucleophiles and possess excellent biological activity and reduced hepatotoxicity (46).

The tolerance at the 17-position for diverse substituents does not affect the formation of HSP90 and geldanamycin or its derivatives (47). So 17-(allylamino)-17-demethoxygeldanamycin (17-AAG), the 17-position derivate of GA, was developed and has shown to have lower in vivo toxicity than GA with even less HSP90 affinity than GA (48). 17-AAG has promising anticancer effects in vitro and in vivo and has completed phase I clinical trials and is in phase II trials for several malignancies including metastatic melanoma, breast and ovarian cancer (49-52). However, poor water solubility makes formulation a barrier for its clinical application (53-55). Additional organic excipients such as dimethylsulfoxide (DMSO), polyoxylcastoroil (Cremophor) and egg phospholipida have been used as vehicles $(53,56)$. However, these excipients may confuse the true maximum tolerated dose of 17-AAG and identificiation of the optional dosing regimen in patients due to their own toxicities. With low doses of 17-AAG
Table II. HSP90 inhibitors.

Geldanamycin series
Geldanamycin
17-AAG
17-DMAG
IPI-504
C-11

Natural

Semisynthetic

Semisynthetic

Synthetic

Synthetic

Radicicol series

Radicicol

Natural

Radicicol oxmie derivates

Semisynthetic

PochoninA-F

Natural

Radamide

Radamide

Synthetic

Novobiocin series

Novobiocin

Novobiocin derivates

Natural

Semisynthetic

\section{(-)-EGCG}

(-)-EGCG

Natural

Derrubone

Derrubone

Natural

Gedunin and celastrol

Gedunin

Natural

Celastrol

Natural

Purine scaffold

Pu3

Synthetic

BIIB021

Synthetic

Pyrazole scaffold

CCTO18159

Synthetic

NVP-AUY922

Synthetic

SNX-2112

SNX-2112 Synthetic

\section{STA9090}

STA9090

Synthetic

in DMSO, researchers did not get objective antitumor responses in several phase II trials including melanoma, hormonerefractory prostate cancer and renal cell carcinoma $(52,57)$. In addition, several characteristics of the chemical structure of 17-AAG have restricted fulfilling the maximal potential of its target in tumor cells (58). A benzoquinone moiety of the molecule has been related to the observed elevation of liver enzymes and liver toxicity in clinical trials. On the other hand, the expression of (P-gp) or loss or mutation of the NQO1 gene, which is necessary for the bio-reduction of 17-AAG, to the more potent hydroquinone have been proposed as mechanisms of de novo or acquired resistance to 17-AAG (58).

The difference between the 17-AAG and 17-DMAG is in the side chain at position 17 of the ansa ring (59). 17-Dimethyl- 
aminoethylamino-17-demethoxygeldanamycin hydrochloride (17-DMAG, NSC 707545) is a more potent, more water soluble derivative of 17-AAG and has potent inhibitory effects on cell proliferation in cultured tumor cell lines and in vivo xenografts, and is currently in phase I clinical trials $(60,61)$. 17-DMAG can be administered orally, which possibly makes it a more feasible long-term therapeutic agent for treating disease (62). 17-DMAG is stable for at least 2 months at room temperature, less bound to plasma proteins compared to 17-AAG, and undergoes limited metabolism $(53,62-64)$. Also, the limited metabolism of 17-DMAG compared to 17-AAG in prelinical models may reduce drug clearance and interindividual pharmacokinetic variability in humans $(62,65)$.

IPI-504 is a highly soluble hydroquinone hydrochloride and novel analogue of 17-allylamino-17-demethoxygeldanamycin, which has $>200 \mathrm{mg} / \mathrm{ml}$ solubility, thereby facilitating formulation for parenteral administration $(55,66)$. The free base of IPI-504 is a potent inhibitor of Hsp90, which exists in a dynamic intracellular equilibrium with 17-AAG $(55,66)$. The half-life of IPI-504 is $\sim 6 \mathrm{~h}$ in vivo, though significant accumulation occurs within tumor cells (66). Phase I trials of IPI-504 in patients with multiple myeloma (MM) and gastrointestinal stromal tumor (GIST) exhibited that the agent was well tolerated at doses up to $300 \mathrm{mg} / \mathrm{m}^{2}$ (67).

Researchers have also synthesized other series of GA or 17-AAG by modification at the various positions. The C-11 modified analogues of GA and 17-AAG were identified with slightly improved cytotoxicity over 17-AAG against several cancer cell lines. The in vitro efficacy and pharmacological profiles of these compounds need further investigation to determine whether these compounds hold any advantages over 17-AAG (68).

Radicicol. Radicicol is a 14-membered macrolide originally isolated from Monosporium bonorden as an anti-fungal antibioticin in 1953 (69). Researchers found that radicicol has the ability to reverse the transformed phenotype in v-src, ras, mos, raf, fos and SV40-transformed cell lines to the normal one and inhibits the expression of mitogen-inducible cyclooxygenase in macrophages (70-73). Radicicol causes cell cycle arrest in the G1 and G2 phase and inhibits angiogenesis in vivo (74). Crystal structure analysis has demonstrated that radicicol acts as a nucleotide mimic, inserting itself into the ATP/ADP-binding pocket of HSP90 (75). Other research groups also indicated that radicicol could bind to the $\mathrm{N}$ terminal GA binding site of HSP90 protein with 50 -fold greater affinity and thus destabilize its client proteins (76-78). Radicicol was found to show potent in vitro anti-proliferative activity against a wide variety of human tumor cell lines, but was inactive when tested against in vivo antitumor models (79).

Radicicol lacks in vivo antitumor activity because the inhibitory effect of radicicol against tyrosine kinases is abolished by reducing agents such as DTT, thus many novel series of derivatives of radicicol have been generated with better stability and biologic activity $(71,80,81)$.

Oxime derivatives were developed and shown to be stable in the presence of thiol (81) such as KF25706, KF29518 and KF58333 were designed and synthesized and were found to show more potent anti-proliferative activities than radicicol and significant in vivo antitumor activities in several human tumor xenograft models $(79,82)$. Researchers reported that KF25706 destabilized HSP90-associated molecules via binding to the HSP90 as radicicol in vitro and exhibited potent antitumor effects in vivo (79). KF58333, also a novel derivative of radicicol, was reported to bind to the Hsp90 chaperone machinery, deplete $\mathrm{p} 210 \mathrm{Bcr}-\mathrm{Abl}$ and Raf-1 proteins followed by induction of erythroid differentiation and G1 phase accumulation, and to induce apoptosis in human CML cells (80).

A new family of resocyclic macrolides was isolated from the fermentation of Pochonia chlamydosporia and named pochonin A-F (83). Pochonin A is closely related to radicicol and was shown to be a 90-nm inhibitor of HSP90 (83). Pochonin $\mathrm{C}$ is also closely related to radicicol and can convert into radicicol (84).

Radamide. Based on the knowledge of co-crystal structures of the HSP90 N-terminal ATP-binding site with radicicol and GA, a chimeric inhibitor, radanamycin amide (radamide), was designed and synthesized via incorporating the key binding interactions provided by the resorcinol ring of radicicol and the quinone moiety of GA into a single molecule $(75,85)$. Radamide exhibited low micromolar inhibition of HSP90 as measured by Her2 degradation in MCF-7 breast cancer cells (85). Chimeric compounds composed of radicicol's resorcinol ring and GA's quinone ring produce potent HSP90 inhibitors and further derivates are likely to afford analogues with increased activity and perhaps useful alternatives to the geldanamycin derivatives in clinical trials $(86,87)$.

Novobiocin. Novobiocin is a type of coumarin antibiotic isolated from streptomyces spheroids, which binds to the ATPbinding pocket of DNA gyrase thus eliciting antimicrobial activity via inhibition of ATP hydrolysis (88-91). Some studies indicated that the HSP90 N-terminal binding domain of GA and radicicol share homology to the bacterial DNA gyrase $\mathrm{B}$ protein adenosine triphosphate (ATP)-binding domain of novobiocin $(21,23,37,77,92,93)$. Researchers began paying attention to the interaction of novobiocin and HSP90. Subsequently, Neckers et al reported that novobiocin binds to a site on HSP90 which is different from the GA/radicicol binding site and shows antitumor activity by reducing HSP90 client protein expression levels, such as p185erbB2, mutated p53, and Raf- 1 in a dose-dependent fashion. They further proposed that the novobiocin binding domain is in the carboxy-terminal portion of HSP90 by using HSP90 deletion mutants (94). Ratajczak et al proposed that novobiocin antagonizes HSP90 function by inducing a conformation favoring separation of the C-terminal domains and release of substrate (95). However, the inhibitory effect was very poor within 500$800 \mu \mathrm{M}$ in SKBR3 breast cancer cells (94). Thereafter, analogues of novobiocin with more potent inhibitory activity were developed.

In 2005, Blagg et al prepared a library of novobiocin analogues, which included shortening of the amide side chain and removal of the 4-hydroxy substituent, removal of both the 4-hydroxy and amide linker, steric replacements of both the 4-hydroxy and benzamide ring, and 1,2-positional isomers 
of the noviosyl linkage. Among them, A4, which contains an $\mathrm{N}$-acetyl side chain in lieu of the benzamide, lacks the 4hydroxyl of the coumarin moiety, and has an unmodified diol, had a dramatic effect on the concentrations of the mutant androgen receptor, AKT, and Hif-1R at a concentration of around $1 \mu \mathrm{M}$ in the $\mathrm{LNCaP}$ cell line and drastically reduced levels of the androgen receptor at lower concentrations in a wild-type androgen receptor prostate cancer cell line (LAPC-4). A4 was identified to be a potent inhibitor of the HSP90 protein-folding process (96). They further explored the structure-activity relationships (SAR) for novobiocin and HSP90 and determined what modifications are necessary to convert a well-established, clinically used DNA gyrase inhibitor, novobiocin, into a selective inhibitor of HSP90. The 4-hydroxyl and the 3-carbamate were found to be detrimental for HSP90 inhibitory activity, but are critical for DNA gyrase inhibitory activity. According the SAR, they prepared the natural product derivatives, DHN1 and DHN2, which were selective for HSP90 and not DNA gyrase (97). The set-up of structure activity relationships for novobiocin and HSP90 are essential for exploring new coumermycin analogues with better inhibitory activity and less toxicity.

In 2006, Blagg et al developed dimeric variants of A4 exhibiting more inhibitory effective of dimeric natural product against Hsp90 protein folding machinery $(98,99)$. A series of A4 analogues were prepared via linking A4 dimers by metaand para-phthalic acid and utilizing the cross-metathesis of olefins to generate a series of compounds that contained various methylene spacers in the tether (99). They found the more flexible derivative 33 dimers containing the olefinic linkers proved to be most active, which caused the degradation of HSP90-dependent substrates in a concentration-dependent manner without additional affect to the non-HSP90-dependent proteins. Further, they proposed that the geometry of the olefin responsible for dimerization is critical for inhibitory activity (99). Considering the structure-activity relationships (SAR), many other monomeric compound based on the A4 scaffold and the natural product novobiocin were developed (100). Two small molecule libraries were prepared and evaluated for anti-proliferative activity against several cancer cell lines. The first library explored optimization of benzamide containing a $p$-methoxy and a $m$-phenyl substituent and the second focused on the incorporation of heterocycles into the benzamide region in order to investigate hydrogen bond donor/acceptor interactions. Especially, 2-indoleamide-46 was identified as the most potent inhibitor which inhibited cancer cell growth via inducing degradation of HSP90dependent client proteins including Her2, Raf and Akt in a concentration-dependent manner (100).

In 2007, a parallel library of noviosylated coumarin analogues was envisioned according to the SAR, which aimed at HSP90 inhibition. Fifty-six noviosylated coumarin analogues were synthesized, omitting 4-hydroxyl and 3carbamate and providing additional hydrophobic and hydrogen bonding interactions by the incorporation of additional functionalities. Biological studies with these compounds are currently under investigation and the results from such studies will promote the development of optimized derivatives of coumarin with better inhibitory effects for HSP90 (101).
Another research group developed novel novobiocin analogues which lack the noviose moiety including those that connect the substituted coumarin ring to the aryl moiety through amide, retroamide, and alkyne linkage. The analogues labeled 6e and 6f were found to be more potent than novobiocin in the biological assay, such as by inhibiting of E2induced and basal transactivation capacity of ERR, inducing a proteasome-mediated degradation of ERR, HER2, Raf-1 and cdk4, inhibiting the cell cycle, and promoting apoptosis and improving growth inhibition potential (102). Subsequently, they prepared the denoviose analogues bearing a tosyl group on the 4-position, with the removal of $\mathrm{C} 7 / \mathrm{C} 8$ substituents, which exhibited increased inhibitory activity against the HSP90 protein folding process (103).

(-)-EGCG. Green tea is one of the most widely consumed beverages in the world. The (-)-epigallocatechin-3-gallate [(-)-EGCG] is an abundant catechin in green tea and a potent chemoprevention and anticancer component (104). (-)-EGCG was reported to inhibit the transcriptional activity of the aryl hydrocarbon receptor (AhR) via direct binding to the Cterminal region of HSP90 (105). Recent studies have indicated that the binding of (-)-EGCG to HSP90 affects the association of HSP90 with its co-chaperones including Akt, Cdk4, Raf-1, Her-2 and pERK, thus inducing degradation of these client proteins, resulting in anti-proliferating effects in pancreatic cancer cells (106).

Gedunin and celastrol. Gedunin is a tetranortriterpenoid isolated from the Indian neem tree, which exhibits antimalarial, insecticidal and anticancer activity (107-109). Celastrol (tripterine) is a triterpenoid from the celastracae family and is extracted from Tripterygium wilfordii Hook F, and has shown anti-inflammatory and anti-proliferation effects in various cancer cells such as leukemia, gliomas and prostate (110-113). Gedunin and celastrol were identified to be HSP90 inhibitors via a connectivity map, a gene expression-based strategy $(114,115)$. Gedunin and celastrol decrease the levels of a range of HSP90 client proteins and inhibit HSP90 activity itself in a cellular context directly or indirectly. Notably, gedunin and celastrol were found to inhibit HSP90 function by a different mechanism than existing N-terminal HSP90 inhibitors, thus they might act synergistically with existing modes of HSP90 ATP-binding site inhibition to inhibit HSP90 client signaling and viability in a cellular context (115). Subsequent studies reported that celastrol disrupted the proteinprotein interaction of HSP90-Cdc3, resulting in the induction of HSP90 client protein degradation, which provides a novel mechanism for HSP90 inhibition against pancreatic cancer cells (116). Recently Sreeramulu et al proposed that celastrol inactivates $\mathrm{Cdc} 37$ by covalently binding to it or by forming either an intra- or intermolecular protein disulfide and the binding of celastrol induces large changes in conformation of the N-terminal kinase-binding domain and also the middle HSP90N-binding domain of $\mathrm{Cdc} 37$, thereby disrupting the Cdc37-Hsp90N complex which is crucial for stabilizing oncogenic kinases in various cancers (117).

Derrubone. The natural product derrubone was found to be a new HSP90 inhibitor by screening a large library of known 
drugs, experimental bioactives and pure natural products (118). Derrubone inhibits HSP90-dependent refolding of luciferase, exhibits potent anti-proliferation and Her2 degradation in human breast cancer cell lines and down-regulates numerous HSP90 client proteins in a concentration-dependent manner (118). Subsequent biological evaluation of derrubone and its analogues identified several compounds which exhibit low micromolar inhibitory activity against breast and colon cancer cell lines (119).

Purine scaffold HSP9O inhibitors. Due to the disadvantages of established inhibitors, the identification of new HSP90 inhibitors with improved structural characteristics and better pharmacological profiles became a priority in the field. Thus purine scaffold HSP90 inhibitors were developed.

In 2001, Chiosis et al designed a novel compound that interacts with the HSP90-nucleotide binding pocket by using the structure of the co-crystals of HSP90 and its ligands (GA, $\mathrm{RD}$ and adenine nucleotides). The designed compound PU3 competes with GA to bind to HSP90A with a relative affinity of 15-20 $\mu \mathrm{M}$. PU3 causes the degradation of HER kinases, estrogen receptor and Raf kinase, and growth inhibition and differentiation of human cancer cells, whose effects were similar to those induced by GA and RD (120). Also, PU3 is soluble, easily synthesized, and may be less toxic and adaptable to oral administration. Although PU3 is less potent, it is a first generation lead compound and the structural skeleton of PU3 allows for extensive chemical modifications in the pursuit of derivatives with increased binding affinity, activity, solubility and therapeutic effects (120). Just as expected, the same research group developed a small library of derivatives of PU3 that resulted in a compound with 30-times better cellular effects than PU3 and display a relative binding affinity for HSP90 of $0.55 \mu \mathrm{M}$ which is similar to 17-AAG. Especially compound 71 caused growth arrest and degradation of the oncogenic Her2 tyrosine kinase at low micromolar (IC50=2 mM) concentrations. Compound 71 is also water soluble at the tested concentrations and is amenable for oral administration (121). Another compound of this library, PU24FCL exhibits antitumor activities in both in vitro and in vivo models of cancer (122). Subsequently, several 8arylsulfanyl, -sulfoxyl and -sulfonyl adenine derivatives of the PU-class were synthesized and retain the activity of the methylene linker compounds $(\mathrm{X} 3=\mathrm{CH} 2)$ and are also chemically flexible which allows for extensive SAR studies (123). Recently, two research groups disclosed the 8-(phenylsulfanyl) purine series with ionizable groups appended at the end of the N(9) substituents, which showed improved oral bioavailability and measurable antitumor activity $(124,125)$.

BIIB021(CNF2024) is the first synthetic HSP90 inhibitor to enter Phase I clinical trials, and was developed based on purine-scaffolds (126). BIIB021 has shown potent antitumor activity both in vivo and in vitro research of many kinds of tumors (127-129). BIIB021 is currently undergoing phase I/II clinical trials and exhibits superior pharmaceutical properties and bioavailability (130).

Pyrazole scaffold inhibitors. The diaryl pyrazole resorcinols were identified by high throughput screening as a new class of HSP90 inhibitors (131-133). The novel synthetic 3,4- diaryl pyrazole resorcinol inhibitor, CCT018159, was identified and showed potent antitumor activity in vitro $(132,134)$. The structure-based design of CCT018159 generated a series of active pyrazole scaffold analogues, that display inhibition of cell proliferation similar to clinically evaluated 17-AAG. The crystal structure of the most potent new compound (VER49009) bound to the target enzyme was determined and confirmed by experiment. VER-49009 binds to the ATP binding site of HSP90 with an IC50 of $25 \mathrm{nM}$ in a fluorescence polarization (FP) assay and has anti-proliferative activity against HCT116 colon cancer cells, with a GI50 of $260 \mathrm{nM}$ (135).

Subsequent structure-based design generated the significantly improved isoxazole resorcinol NVP-AUY922, which is currently under phase I/II clinical trials in cancer patients (136). NVP-AUY922 has excellent potency against HSP90 in an FP binding assay (IC50=21 nM), inhibits proliferation in a wide range of human cancer cell lines with an average GI50 of $9 \mathrm{nM}$ and shows excellent efficacy in a range of subcutaneous and orthotopic human tumor xenograft models covering major cancer types and diverse oncogenic profiles. In addition, it is retained in HCT116 xenograft tumors at concentrations well above the GI50, with a half-life of $9.5 \mathrm{~h}$ following i.p. administration at $50 \mathrm{mg} / \mathrm{kg}$ qd (136). During its early clinical phases, it was considered that PET biomarkers could aid in the optimization of dosing and dose schedule (137).

SNX-2112. SNX-2112 is a newly developed HSP90 inhibitor that is unrelated to any previously known scaffold. The SNX-2112 scaffold was identified by screening the purinebinding proteome for non-quinone and non-purine-containing scaffolds that bind selectively to HSP90 and it is panselective for the HSP90 family in that it binds to Hsp90a, HSP90B, Grp94 and Trap-1. A water-soluble prodrugs of SNX-2112, SNX-5542, was developed and showed improved solubility and pharmacologic properties due to the variable oral bioavailability of SNX-2112 (138). SNX-2112 and its prodrug SNX-5542 showed similar activity as 17-AAG, such as the degradation of HER2, mutant epidermal growth factor receptor and other client proteins; the inhibition of extracellular signal regulated kinase and Akt activation, and the induction of an Rb-dependent G1 arrest with subsequent apoptosis (138). Further study exhibited that SNX-2112 is highly potent against hematologic tumor cells via abrogating signaling which is dependent on Akt and Erk and induces tumor growth inhibition and prolongs survival in a murine xenograft model of human multiple myeloma $(139,140)$. SNX-2112 is now in multiple phase I clinical trials.

STA9090. STA9090 developed by Synta Pharmaceuticals Corp. is a novel resorcinol containing a triazole compound unrelated to geldanamycin and acts as a potent HSP90 inhibitor (141). STA-9090 causes the degradation of multiple HSP90 client proteins, the killing of a wide variety of human cancer cell lines at low nano molar concentrations in vitro, and has shown potent anticancer activity in human xenograft tumor models (142). STA9090 is currently undergoing phase I or phase I/II trials (http://www.gistsupport.org/treatments/ emerging-treatments/HSP90-inhibitors/sta-9090.php). 


\section{Conclusions}

The HSP90 molecular chaperone family is highly conserved and expressed in various organisms ranging from prokaryotes to eukaryotes. HSP90 proteins play essential housekeeping functions and play an important role in the progression of malignant disease. HSP90 proteins are ATP-dependent chaperones and the binding and hydrolysis of ATP is coupled to conformation changes of HSP90, which facilitates client protein folding and maturation. Many natural and synthetic molecular compounds have been proposed as promising cancer therapies via disrupting the formation of complex ATPHSP90-client proteins.

\section{References}

1. Csermely P, Schnaider T, Soti C, Prohászka Z and Nardai G: The 90-kDa molecular chaperone family: structure, function and clinical applications. a comprehensive review. Pharmacol Ther 79: 129-168, 1998 .

2. Buchner J: Hsp90 \& Co. - a holding for folding. Trends Biochem Sci 24: 136-141, 1999.

3. Bagatell R and Whitesell L: Altered Hsp90 function in cancer: a unique therapeutic opportunity. Mol Cancer Ther 3: 1021-1030, 2004.

4. Pratt WB and Toft DO: Regulation of signaling protein function and trafficking by the Hsp90/hsp70-based chaperone machinery. Exp Biol Med (Maywood) 228: 111-133, 2003.

5. Lanneau D, Brunet M, Frisan E, Solary E, Fontenay M and Garrido C: Heat shock proteins: essential proteins for apoptosis regulation. J Cell Mol Med 12: 743-761, 2008.

6. Clarke PA, Hostein I, Banerji U, Stefano FD, Maloney A, Walton M, Judson I and Workman P: Gene expression profiling of human colon cancer cells following inhibition of signal transduction by 17-allylamino-17-demethoxy-geldanamycin, an inhibitor of the Hsp90 molecular chaperone. Oncogene 19: 4125-4133, 2000.

7. Burrows F, Zhang $\mathrm{H}$ and Kamal A: HSP90 activation and cell cycle regulation. Cell Cycle 3: 1530-1536, 2004.

8. Ferrarini M, Heltai S, Zocchi MR and Rugarli C: Unusual expression and locization of heat shock protein in human tumor cells. Int J Cancer 51: 613-619, 1992

9. Ruden DM, Xiao L, Garfinkel MD and Lu X: Hsp90 and environmental impacts on epigenetic states: a model for the transgenerational effects of diethylstibesterol on uterine development and cancer. Hum Mol Genet 14: R149-R155, 2005.

10. Felts SJ, Owen BA, Nguyen P, Trepel J, Donner DB and Toft DO: The Hsp90-related protein TRAP1 is a mitochondrial protein with distinct functional properties. J Biol Chem 275: 3305-3312, 2000.

11. Krishna P and Gloor G: The Hsp90 family of proteins in Arabidopsis thaliana. Cell Stress Chaperon 6: 238-246, 2001.

12. Rebbe NF, Ware J, Bertina RM, Modrich P and Stafford DW: Nucleotide sequence of a cDNA for a member of the human 90-kDa heat-shock protein family. Gene 53: 235-245, 1987.

13. Hoffmann T and Hovemann B: Heat-shockproteins, Hsp84 and Hsp86, of mice and men: two related genes encode formerly identified tumour-specific transplantation antigens. Gene 74 : 491-501, 1988 .

14. Chen B, Piel WH, Gui L, Bruford E and Monteiro A: The HSP90 family of genes in the human genome: insights into their divergence and evolution. Genomics 86: 627-637, 2005.

15. Krone PH and Sass JB: Hsp90a and Hsp90ß genes are present in the zebrafish and are differentially regulated on developing embryos. Biochem Biophys Res Commun 204: 746-752, 1994.

16. Stechmann A and Cavalier-Smith T: Evolutionary origins of Hsp90 chaperones and a deep paralogy in their bacterial ancestors. J Eukaryot Microbiol 51: 364-373, 2004.

17. Song HY, Dunbar JD, Zhang YX, Guo D and Donner DB: Identification of a protein with homology to Hsp90 that binds the type 1 tumor necrosis factor receptor. J Bio Chem 270: 3574-3581, 1995.

18. Grammatikakis N, Vultur A, Ramana CV, Siganou A, Schweinfest CW, Watson DK and Raptis L: The role of HSP90N, a new member of the Hsp90 family, in signal transduction and neoplastic transformation. J Bio Chem 277: 8312-8320, 2002.
19. Shiau AK, Harris SF, Southworth DR and Agard DA: Structural analysis of $E$. coli Hsp90 reveals dramatic nucleotide-dependent conformational rearrangements. Cell 127: 329-340, 2006.

20. Huai Q, Wang H, Liu Y, Kim HY, Toft D and Ke H: Structures of the N-terminal and middle domains of E. coli Hsp90 and conformation changes upon ADP binding. Structure 13: 579-590, 2005.

21. Prodromou C, Roe SM, O'Brien R, Ladbury JE, Piper PW and Pearl LH: Identification and structural characterization of the ATP/ADP-binding site in the Hsp90 molecular chaperone. Cell 90: 65-75, 1997.

22. Ali MM, Roe SM, Vaughan CK, Meyer P, Panaretou B, Piper PW, Prodromou C and Pearl LH: Crystal structure of an Hsp90nucleotide-p23/Sba1 closed chaperone complex. Nature 440: 1013-1017, 2006.

23. Stebbins CE, Russo AA, Schneider C, Rosen N, Hartl FU and Pavletich NP: Crystal structure of an Hsp90-geldanamycin complex: targeting of a protein chaperone by an antitumor agent. Cell 89: 239-250, 1997.

24. Richter K, Soroka J, Skalniak L, Leskovar A, Hessling M, Reinstein J and Buchner J: Conserved conformational changes in the ATPase cycle of human Hsp 90. J Biol Chem 283: 17757-17765, 2008

25. Garnier C, Lafitte D, Tsvetkov PO, Barbier P, Leclerc-Devin J, Millot JM, Briand C, Makarov AA, Catelli MG and Peyrot V: Binding of ATP to heat shock protein 90: evidence for an ATPbinding site in the C-terminal domain. J Biol Chem 277 : 12208-12214, 2002.

26. Minami Y, Kawasaki H, Suzuki K and Yahara I: The calmodulinbinding domain of the mouse $90-\mathrm{kDa}$ heat shock protein. J Biol Chem 268: 9604-9610, 1993.

27. Minami Y, Kimura Y, Kawasaki H, Suzuki K and Yahara I: The carboxy-terminal region of mammalian HSP90 is required for its dimerization and function in vivo. Mol Cell Biol 14: 1459-1464, 1994.

28. Chen S, Sullivan WP, Toft DO and Smith DF: Differential interactions of p23 and the TPR-containing proteins Hop, Cyp40, FKBP52 and FKBP51 with Hsp90 mutants. Cell Stress Chaperones 3: 118-129, 1998.

29. Prodromou C, Siligardi G, O'Brien R, Woolfson DN, Regan L, Panaretou B, Ladbury JE, Piper PW and Peral LH: Regulation of Hsp90 ATPase activity by tetratricopeptide repeat (TPR)domain co-chaperones. EMBO J 18: 754-762, 1999.

30. Scheufler C, Brinker A, Bourenkov G, Pegoraro S, Moroder L, Bartunik H, Harl FU and Moarefi I: Structure of TPR domainpeptide complexes: critical elements in the assembly of the Hsp70-Hsp90 multichaperone machine. Cell 101: 199-210, 2000.

31. Hawl P, Siepmann M, Harst A, Siderius M, Reusch HP and Obermann WM: The middle domain of Hsp90 acts as a discriminator between different types of client proteins. Mol Cell Biol 26: 8385-8395, 2006.

32. Harst A, Lin H and Obermann WM: Aha1 competes with Hop p50 and p23 for binding to the molecular chaperone Hsp90 and contributes to kinase and hormone receptor activation. Biochem J 387: 789-796, 2005.

33. Lotz GP, Lin H, Harst A and Obermann WM: Aha1 binds to the middle domain of $\mathrm{Hsp} 90$, contributes to client protein activation, and stimulates the ATPase activity of the molecular chaperone. J Biol Chem 278: 17228-17235, 2003.

34. Meyer P, Prodromou C, Hu B, Vaughan C, Roe SM, Panaretou B, Piper PW and Pearl LH: Structural and functional analysis of the middle segment of Hsp90: implications for ATP hydrolysis and client protein and cochaperone interactions. Mol Cell 11: 647-658, 2003.

35. Panaretou B, Siligardi G, Meyer P, Maloney A, Sullivan JK, Singh S, Millson SH, Clarke PA, Naaby-Hansen S, Stein R, Cramer R, Mollapour M, Workman P, Piper PW, Pearl LH and Prodromou C: Activation of the ATPase activity of Hsp90 by the stress-regulated cochaperone aha1. Mol Cell 10: 1307-1318, 2002.

36. Prodromou C, Roe SM, Piper PW and Pearl LH: A molecular clamp in the crystal structure of the N-terminal domain of the yeast Hsp90 chaperone. Nature Struct Biol 4: 477-482, 1997.

37. Grenert JP, Sullivan WP, Fadden P, Haystead TA, Clark J, Mimnaugh E, Krutzsch H, Ochel HJ, Schulte TW, Sausville E, Neckers LM and Toft DO: The amino-terminal domain of heat shock protein90 (Hsp90) that binds Geldanamycin is an ATP/ADP switch domain that regulates Hsp90 conformation. J Biol Chem 272: 23843-23850, 1997. 
38. Obermann WM, Sondermann H, Russo AA, Pavletich NP and Hartl FU: In vivo function of Hsp90 is dependent on ATP binding and ATP hydrolysis. J Cell Biol 143: 901-910, 1998.

39. Panaretou B, Prodromou C, Roe SM, O'Brien R, Ladbury JE, Piper PW and Pearl LH: ATP binding and hydrolysis are essential to the function of the Hsp90 molecular chaperone in vivo. EMBO J 17: 4829-4836, 1998.

40. Chadli A, Bouhouche I, Sullivan W, Stensgard B, McMahon N, Catelli MG and Toft DO: Dimerization and N-terminal domain proximity underlie the function of the molecular chaperone heat shock protein 90. Proc Natl Acad Sci USA 97: 12524-12529, 2000.

41. Young JC, Moarefi I and Hartl FU: Hsp90: a specialized but essential protein-folding tool. J Cell Biol 154: 267-273, 2001.

42. Söti C, Rácz A and Csermely P: A Nucleotide-dependent molecular switch controls ATP binding at the C-terminal domain of Hsp90. N-terminal nucleotide binding unmasks a C-terminal binding pocket. J Biol Chem 277: 7066-7075, 2002.

43. Richter K, Moser S, Hagn F, Friedrich R, Hainzl O, Heller M, Schlee S, Kessler H, Reinstein J and Buchner J: Intrinsic inhibition of the Hsp90 ATPase activity. J Biol Chem 281: 11301-11311, 2006.

44. Whitesell L, Mimnaugh EG, De Costa B, Myers CE and Neckers LM: Inhibition of heat shock protein HSP90-pp6Ov-src heteroprotein complex formation by benzoquinone ansamycins: essential role for stress proteins in oncogenic transformation. Proc Natl Acad Sci USA 91: 8324-8328, 1994.

45. Supko JG, Hickman RL, Grever MR and Malspeis L: Preclinical pharmacologic evaluation of geldanamycin as an antitumor agent. Cancer Chemother Pharmacol 36: 305-315, 1995.

46. Schnur RC, Corman ML, Gallaschun RJ, et al: Inhibition of the oncogene product p185erbB-2 in vitro and in vivo by geldanamycin and dihydrogeldanamycin derivatives. J Med Chem 38: 3806-3812, 1995

47. Tian ZQ, Liu Y, Zhang D, Wang Z, Dong SD, Carreras CW, Zhou Y, Rastelli G, Santi DV and Myles DC: Synthesis and biological activities of novel 17-aminogeldanamycin derivatives. Bioorg Med Chem 12: 5317-5329, 2004

48. Schulte TW and Neckers LM: Thebenzoquinone ansamycin 17-allylamino-17-demethoxygeldanamycin binds to HSP90 and shares important biologic activities with geldanamycin. Cancer Chemother Pharmacol 42: 273-279, 1998.

49. Solit DB and Chiosis G: Development and application of Hsp90 inhibitors. Drug Discovery Today 13: 38-43, 2008.

50. Hostein I, Robertson D, Di Stefano F, Workman P and Clarke PA Inhibition of signal transduction by the Hsp90 inhibitor 17 allylamino-17-demethox-ygeldanamycin results in cytostasis and apoptosis. Cancer Res 61: 4003-4009, 2001

51. Münster PN, Basso A, Solit D, Norton L and Rosen N: Modulation of Hsp90 function by ansamycins sensitizes breast cancer cells to chemotherapy-induced apoptosis in an RB- and schedule-dependent manner. See: E.A. Sausville, combining cytotoxics and 17-allylamino, 17-demethoxy-geldanamycin: sequence and tumor biology matters. Clin Cancer Res 7: 21552158,2001

52. Ronnen EA, Kondagunta GV, Ishill N, Sweeney SM, Deluca JK, Schwartz L, Bacik J and Motzer RJ: A phase II trial of 17 (allylamino)-17-demethoxygeldanamycin in patients with papillary and clear cell renal cell carcinoma. Invest New Drugs 24: 543-546, 2006

53. Egorin MJ, Zuhowski EG, Rosen DM, Sentz DL, Covey JM and Eiseman JL: Plasma pharmacokinetics and tissue distribution of 17-(allylamino)-17-demethoxygeldanamycin (NSC330507) in CD2F1 mice1. Cancer Chemother Pharmacol 47: 291-302, 2001

54. Guo W, Reigan P, Siegel D, Zirrolli J, Gustafson D and Ross D: Formation of 17-allylamino-demethoxy-geldanamycin (17AAG) hydroquinone by $\mathrm{NAD}(\mathrm{P}) \mathrm{H}$ : quinone oxidoreductase 1 : role of 17-AAG hydroquinone in heat shock protein 90 inhibition. Cancer Res 65: 10006-10015, 2005.

55. Ge J, Normant E, Porter JR, Ali JA, Dembski MS, GaoY, Georges AT, Grenier L, Pak RH, Patterson J, Sydor JR, Tibbitts TT, Tong JK, Adams J and Palombella VJ: Design, synthesis, and biological evaluation of hydroquinone derivatives of 17-amino-17-demethoxygeldanamycin as potent, watersoluble inhibitors of Hsp90. J Med Chem 49: 4606-4615, 2006

56. Sausville EA, Tomaszewski JE and Ivy P: Clinical development of 17-allylamino,17-demethoxy-geldanamycin. Curr Cancer Drug Targets 3: 377-383, 2003.
57. Solit DB, Osman I, Polsky D, Panageas KS, Daud A, Goydos JS Teitcher J, Wolchok JD, Germino FJ, Krown SE, Coit D, Rosen N and Chapman PB: PhaseII trial of 17-allylamino-17-demethoxy geldanamycin in patients with metastatic melanoma. Clin Cancer Res 14: 8302-8307, 2008

58. Chiosis G, Caldas Lopes E and Solit D: Heat shock protein-90 inhibitors a chronice from geldanamycin to today's agents. Curr Opin Investig Drugs 7: 534-541, 2006.

59. Smith V, Sausville EA, Camalier RF, Fiebig HH and Burger AM: Comparison of 17-dimethylaminoethylamino-17-demethoxygeldanamycin (17DMAG) and 17-allylamino-17-demethoxygeldanamycin (17AAG) in vitro: effects on Hsp90 and client proteins in melanoma models. Cancer Chemother Pharmacol 56: 126-137, 2005.

60. Hollingshead M, Alley M, Burger AM, Borgel S, Pacula-Cox C, Fiebig HH and Sausville EA: In vivo antitumor efficacy of 17DMAG (17-dimethylaminoethylamino-17-demethoxygeldanamycinhydrochloride) a water-soluble geldanamycin derivative. Cancer Chemother Pharmacol 56: 115-125, 2005.

61. Hwang K, Scripture CD, Gutierrez M, Kummar S, Figg WD and Sparreboom A: Determination of the heat shock protein 90 inhibitor 17-dimethyl aminoethylamino-17-demethoxygeldanamycin in plasma by liquid chromatography-electrospray mass spectrometry. J Chromatogr B Analyt Technol Biomed Life Sci 830: 35-40, 2006

62. Egorin MJ, Lagattuta TF, Hamburger DR, Covey JM, White KD, Musser SM and Eiseman JL: Pharmaco kinetics, tissue distribution and metabolism of 17-(dimethylaminoethylamino)-17demethoxygeldanamycin (NSC707545) in CD2F1 mice and Fischer 344 rats. Cancer Chemother Pharmacol 49: 7-19, 2002.

63. Glaze ER, Lambert AL, Smith AC, Page JG, Johnson WD, McCormick DL, Brown AP, Levine BS, Covey JM, Egorin MJ, Eiseman JL, Holleran JL, Sausville EA and Tomaszewski JE: Preclinical toxicity of a geldanamycin analog, 17-(dimethylaminoethylamino)-17-demethoxygeldanamycin (17-DMAG), in rats and dogs: potential clinical relevance. Cancer Chemother Pharmacol 56: 637-647, 2005.

64. Egorin MJ, Rosen DM, Wolff JH, Callery PS, Musser SM and Eiseman JL: Metabolism of 17-(allylamino)-17-demethoxygeldanamycin (NSC 330507) by murine and human hepatic preparations. Cancer Res 58: 2385-2396, 1998.

65. Eiseman JL, Lan J, Lagattuta TF, Hamburger DR, Joseph E, Covey JM and Egorin MJ: Pharmacokinetics and pharmacodynamics of 17-demethoxy 17-\{[(2-dimethylamino)ethyl]amino $\}$ geldanamycin (17DMAG, NSC 707545) in C.B-17 SCID mice bearing MDA-MB-231 human breast cancer xenografts. Cancer Chemother Pharmacol 55: 21-32, 2005.

66. Sydor JR, Normant E, Pien CS, Porter JR, Ge J, Grenier L, Pak RH, Ali JA, Dembski MS, Hudak J, Patterson J, Penders C, Pink M, Read MA, Sang J, Woodward C, Zhang Y, Grayzel DS, Wright J, Barrett JA, Palombella VJ, Adams J and Tong JK: Development of 17-allylamino-17-demethoxygel-danamycin hydroquinone hydrochloride (IPI-504), an anti-cancer agent directed against Hsp90. Proc Natl Acad Sci USA 103: 17408-17413, 2006

67. Siegel D, Jagannath S, Mazumder A, Vesole D, Borrello I, Sydor JR, Wright J, Patterson J, Normant E, Adams J, Anderson KC, Grayzel DS and Richardson PG: Update on phase I clinical trial of IPI-504, a novel, water soluble Hsp90 inhibitor, in patients with relapsed/refractory multiple myeloma. (ASH Annual Meeting Abstracts) Blood 108: abs. 3579, 2006.

68. Tian ZQ, Wang Z, MacMillan KS, Zhou Y, Carreras CW, Mueller T, Myles DC and Liu Y: Potent cytotoxic C-11 modified geldanamycin analogues. J Med Chem 52: 3265-3273, 2009.

69. Ki SW, Ishigami K, Kitahara T, Kasahara K, Yoshida M and Horinouchi S: Radicicol binds and inhibits mammalian ATP citrate lyase. J Biol Chem 275: 39231-39236, 2000.

70. Kwon HJ, Yoshida M, Abe K, Horinouchi S and Beppu T: Radicicol, an agent inducing the reversal of transformed phenotypes of src-transformed fibroblasts. Biosc Biotech Biochem 56: 538-539, 1992.

71. Kwon HJ, Yoshida M, Fukui Y, Horinouchi S and Beppu T: Potent and specific inhibition of p60v-src protein kinase both in vivo and in vitro by radicicol. Cancer Res 52: 6926-6930, 1992.

72. Kwon HJ, Yoshida M, Muroya K, Hattori S, Nishida E, Fukui Y, Beppu T and Horinouchi S: Morphology of ras-transformed cells becomes apparently normal again with tyrosine kinase inhibitors without a decrease in the ras-GTP complex. J Biochem 118: 221-228, 1995 . 
73. Chanmugam P, Feng L, Liou S, Lee JH, Jang BC, Boudreau M, Yu G, Kwon HJ, Beppu T, Yoshida M, Xia Y, Wilson CB and Hwang D: Radicicol, a protein tyrosine kinase inhibitor, suppresses the expression of mitogen-inducible cyclooxygenase in macrophages stimulated with lipopolysaccharide and in experimental glomerulonephritis. J Biol Chem 270: 5418-5426, 1995.

74. Oikawa T, Ito H, Ashino H, Toi M, Tominaga T, Morita I and Murota S: Radicicol, a microbial cell differentiation modulator, inhibits in vivo angiogenesis. Eur J Pharmacol 241: 221-227, 1993.

75. Roe SM, Prodromou C, O'Brien R, Ladbury JE, Piper PW and Pearl LH: Structural basis for inhibition of the Hsp90 molecular chaperone by the antitumor antibiotics radicicol and geldanamycin. J Med Chem 42: 260-266, 1999.

76. Soga S, Kozawa T, Narumi H, Akinaga S, Irie K, Matsumoto K, Sharma SV, Nakano H, Mizukami T and Hara M: Radicicol leads to selective depletion of raf kinase and disrupts K-rasactivated aberrant signaling pathway. J Biol Chem 273: 822-828, 1998.

77. Schulte TW, Akinaga S, Soga S, Sullivan W, Stensgard B, Toft D and Neckers LM: The antibiotic radicicol to the N-terminal domain of Hsp90 and shares important biological activities with geldanamycin. Cell Stress Chaperones 3: 100-108, 1998.

78. Sharma SV, Agatsuma $\mathrm{T}$ and Nakano H: Targeting of the protein chaperone, Hsp90, by the transformation suppressing agent, radicicol. Oncogene 16: 2639-2645, 1998

79. Soga S, Neckers LM, Schulte TW, Shiotsu Y, Akasaka K Narumi H, Agatsuma T, Ikuina Y, Murakata C, Tamaoki T and Akinaga S: KF25706, a novel oxime derivative of radicicol, exhibits in vivo antitumor activity via selective depletion of Hsp90 binding signaling molecules. Cancer Res 59: 2931-2938, 1999.

80. Shiotsu Y, Neckers LM, Wortman I, An WG, Schulte TW, Soga S, Murakata C, Tamaoki T and Akinaga S: Novel oxime derivatives of radicicol induce erythroid differentiation associated with preferential G1 phase accumulation against chronic myelogenous leukemia cells through destabilization of Bcr-Abl with Hsp90 complex. Blood 96: 2284-2291, 2000.

81. Kwon HJ, Yoshida M, Nagaoka R, Obinata T, Beppu T and Horinouchi S: Suppression of morphological transformation by radicicol is accompanied by enhanced gelsolin expression. Oncogene 15: 2625-2631, 1997

82. Agatsuma T, Ogawa H, Akasaka K, Asai A, Yamashita Y, Mizukami T, Akinaga S and Saitoh Y: Halohydrin and oxime derivatives of radicicol: synthesis and antitumor activities. Bioorg Med Chem 10: 3445-3454, 2002.

83. Hellwig V, Mayer-Bartschmid A, Muelle H, Greif G, Kleymann G, Zitzmann W, Tichy HV and Stadler M Pochonins A-F, new antiviral and antiparasitic resorcylic acid lactones from Pochonia chlamydosporia var. catenulata. J Nat Prod 66: 829-837, 2003.

84. Barluenga S, Lopez P, Moulin E and Winssinger N: Modular asymmetric synthesis of pochonin C. Angew Chem Int Ed Engl 43: 3467-3470, 2004

85. Clevenger RC and Blagg BS: Design, synthesis and evaluation of a radicicol and geldanamycin chimera radamide. Org Lett 6 : 4459-4462, 2004

86. Wang M, Shen G and Blagg BS: Radanamycin, a macrocyclic chimera of radicicol and geldanamycin. Bioorg Med Chem Lett 16: 2459-2262, 2006

87. Hadden MK and Blagg BS: Synthesis and evaluation of radamide analogues, a chimera of radicicol and geldanamycin. J Org Chem 74: 4697-4704, 2009.

88. Hooper DC, Wolfson JS, McHugh GL, Winters MB and Swartz MN: Effects of novobiocin, coumermycin A1, clorobiocin and their analogs on Escherichia coli DNA gyrase and bacterial growth. Antimicrob Agents Chemother 22: 662-671, 1982

89. Tanitame A, Oyamada Y, Ofuji K, Fujimoto M, Suzuki K, Ueda T, Terauchi H, Kawasaki M, Nagai K, Wachi M and Yamagishi J: Synthesis and antibacterial activity of novel and potent DNA gyrase inhibitors with azole ring. Bioorg Med Chem 12: 5515-5524, 2004.

90. Laurin P, Ferroud D, Schio L, Klich M, Dupuis-Hamelin C, Mauvais P, Lassaigne P, Bonnefoy A and Musicki B Structure-activity relationship in two series of aminoalkyl substituted coumarin inhibitors of gyrase B. Bioorg Med Chem Lett 9: 2875-2880, 1999 .
91. Ali JA, Jackson AP, Howells AJ and Maxwell A: The 43-kilodalton N-terminal fragment of the DNA gyrase B protein hydro-lyzes ATP and binds coumarin drugs. Biochemistry 32: 2717-2724, 1993.

92. Bergerat A, De Massy B, Gadelle D, Varoutas PC, Nicolas A and Forterre P: An atypical topoisomerase II from Archaea with implications for meiotic recombination. Nature 386: 414-417, 1997

93. Schulte TW, Akinaga S, Murakata T, Agatsuma T, Sugimoto S, Nakano H, Lee YS, Simen BB, Argon Y, Felts S, Toft DO, Neckers LM and Sharma SV: Interaction of radicicol with members of the heat shock protein 90 family of molecular chaperones. Mol Endocrinol 13: 1435-1448, 1999.

94. Marcu MG, Schulte TW and Neckers L: Novobiocin and related coumarins and depletion of heat shock protein 90 dependent signaling proteins. J Natl Cancer Inst 92: 242-248, 2000

95. Allan RK, Mok D, Ward BK and Ratajczak T: Modulation of chaperone function and cochaperone interaction by novobiocin in the C-terminal domain of Hsp90. J Biol Chem 281: 7161-7171, 2006.

96. Yu XM, Shen G, Neckers L, Blake H, Holzbeierlein J, Cronk B and Blagg BS: Hsp90 inhibitors identified from a library of novobiocin analogues. J Am Chem Soc 127: 12778-12779, 2005.

97. Burlison JA, Neckers L, Smith AB, Maxwell A and Blagg BS: Novobiocin: redesigning a DNA gyrase inhibitor for selective inhibition of Hsp90. J Am Chem Soc 128: 15529-15536, 2006.

98. Marcu MG, Chadli A, Bouhouche I, Catelli M and Neckers LM: The heat shock protein 90 antagonist novobiocin interacts with a previously unrecognized ATP-binding domain in the carboxyl terminus of the chaperone. J Biol Chem 275: 37181-37186, 2000 .

99. Burlison JA and Blagg BS: Synthesis and evaluation of coumermycin A1 analogues that inhibit the Hsp90 protein folding machinery. Org Lett 8: 4855-4858, 2006.

100. Burlison JA, Avila C, Vielhauer G, Lubbers DJ, Holzbeierlein J and Blagg BS: Development of novobiocin analogues that manifest anti-proliferative activity against several cancer cell lines. J Org Chem 73: 2130-2137, 2008.

101. Huang YT and Blagg BS: A library of noviosylated coumarin analogues. J Org Chem 72: 3609-3613, 2007.

102. Le Bras G, Radanyi C, Peyrat JF, Brion JD, Alami M, Marsaud V, Stella B and Renoir JM: New novobiocin analogues as antiproliferative agents in breast cancer cells and potential inhibitors of heat shock protein 90. J Med Chem 50: 6189-6200, 2007.

103. Radanyi C, Le Bras G, Messaoudi S, Bouclier C, Peyrat JF, Brion JD, Marsaud V, Renoir JM and Alami M: Synthesis and biological activity of simplified denoviose-coumarins related to novobiocin as potent inhibitors of heat-shock protein 90 (Hsp90). Bioorg Med Chem Lett 18: 2495-2498, 2008

104. Fujiki H: Two stages of cancer prevention with green tea. J Cancer Res Clin Oncol 125: 589-597, 1999.

105. Palermo CM, Westlake CA and Gasiewicz TA: Epigallocatechin gallate inhibits aryl hydrocarbon receptor gene transcription through an indirect mechanism involving binding to a 90-kDa heat shock protein. Biochemistry 44: 5041-5052, 2005.

106. Li Y, Zhang T, Jiang Y, Lee HF, Schwartz SJ and Sun D: (-)Epigallocatechin-3-gallate inhibits Hsp90 function by impairing Hsp90 association with cochaperones in pancreatic cancer cell line Mia Paca-2. Mol Pharm 6: 1152-1159, 2009.

107. Khalid SA, Duddeck H and Gonzalez-Sierra M: Isolation and characterization of an antimalarial agent of the neem tree Azadirachta indica. J Nat Prod 52: 922-926, 1989.

108. Nathan SS, Kalaivani K, Chang PG and Murugan K: Effect of neem limonoids on lactate dehydrogenase (LDH) of the rice leaf holder, C naphalocrocismedinalis (Guenee) (Insecta: Lepidoptera: Pyralidae). Chemosphere 62: 1388-1393, 2006.

109. Uddin SJ, Nahar L, Shilpi JA, Shoeb M, Borkowski T, Gibbons S, Middleton M, Byres M and Sarker SD: Gedunin, a limonoid from Xylocarpus granatum, inhibits the growth of CaCo-2 colon cancer cell line in vitro. Phytother Res 21: 757-761, 2007

110. Calixto JB, Campos MM, Otuki MF and Santos AR: Antiinflammatory compounds of plant origin. Part II: modulation of pro-inflammatory cytokines, chemokines and adhesion molecules. Planta Med 70: 93-103, 2004. 
111. Guo JL, Yuan SX, Wang XC, Xu SX and Li DD: Tripterygium wilfordii Hook $\mathrm{f}$ in rheumatoid arthritis and ankylosing spondylitis. Preliminary report. Chin Med J (Engl) 94: 405-412, 1981.

112. Nagase M, Oto J, Sugiyama S, Yube K, Takaishi Y and Sakato N: Apoptosis induction in HL-60 cells and inhibition of topoisomerase II by triterpene celastrol. Biosci Biotechnol Biochem 67: 1883-1887, 2003.

113. Yang H, Chen D, Cui QC, Yuan X and Dou QP: Celastrol, a triterpene extracted from the Chinese 'Thunder of God Vine' is a potent proteasome inhibitor and suppresses human prostate cancer growth in nude mice. Cancer Res 66: 4758-4765, 2006.

114. Lamb J, Crawford ED, Peck D, Modell JW, Blat IC, Wrobel MJ, Lerner J, Brunet JP, Subramanian A, Ross KN, Reich M, Hieronymus H, Wei G, Armstrong SA, Haggarty SJ, Clemons PA, Wei R, Carr SA, Lander ES and Golub TR: The connectivity map: using gene expression signatures to connect small molecules, genes and disease. Science 313: 1929-1935, 2006.

115. Hieronymus H, Lamb J, Ross KN, Peng XP, Clement C, Rodina A, Nieto M, Du J, Stegmaier K, Raj SM, Maloney KN, Clardy J, Hahn WC, Chiosis G and Golub TR: Gene expression signature based chemical genomic prediction identifies a novel class of HSP90 pathway modulators. Cancer Cell 10: 321-330, 2006.

116.Zhang T, Hamza A, Cao X, Wang B, Yu S, Zhan CG and Sun D: A novel Hsp90 inhibitor to disrupt Hsp90/Cdc37complex against pancreatic cancer cells. Mol Cancer Ther 7: 162-170, 2008.

117. Sreeramulu S, Gande SL, Göbel M and Schwalbe H: Molecular mechanism of inhibition of the human protein complex Hsp90Cdc37, a kinome chaperone-cochaperone, by triterpene celastrol. Angew Chem Int Ed Engl 48: 5853-5855, 2009.

118. Hadden MK, Galam L, Gestwicki JE, Matts RL and Blagg BS Derrubone, an inhibitor of the Hsp90 protein folding machinery. J Nat Prod 70: 2014-2018, 2007.

119. Hastings JM, Hadden MK and Blagg BS: Synthesis and evaluation of derrubone and select analogues. J Org Chem 73: 369-373, 2008.

120. Chiosis G, Timaul MN, Lucas B, Munster PN, Zheng FF, Sepp-Lorenzino L and Rosen N: A small molecule designed to bind to the adenine nucleotide pocket of Hsp90 causes Her2 degradation and the growth arrest and differentiation of breast cancer cells. Chem Biol 8: 289-299, 2001

121. Chiosis G, Lucas B, Shtil A, Huezo H and Rosen N: Development of a purine-scaffold novel class of Hsp90 binders that inhibit the proliferation of cancer cells and induce the degradation of Her2 tyrosine kinase. Bioorg Med Chem 10: $3555-3564,2002$

122. Vilenchik M, Solit D, Basso A, Huezo H, Lucas B, He H, Rosen N, Spampinato C, Modrich P and Chiosis G: Targeting wide-range oncogenic transformation via $\mathrm{PU} 24 \mathrm{FCl}$, a specific inhibitor of tumor Hsp90. Chem Biol 11: 787-797, 2004

123. Llauger L, He H, Kim J, Aguirre J, Rosen N, Peters U, Davies P and Chiosis G: Evaluation of 8-arylsulfanyl, 8-arylsulfoxyl, and 8-arylsulfonyl adenine derivatives as inhibitors of the heat shock protein 90. J Med Chem 48: 2892-2905, 2005.

124. Biamonte MA, Shi J, Hong K, Hurst DC, Zhang L, Fan J, Busch DJ, Karjian PL, Maldonado AA, Sensintaffar JL, Yang YC, Kamal A, Lough RE, Lundgren K, Burrows FJ, Timony GA, Boehm MF and Kasibhatla SR: Orally active purine-based inhibitors of Hsp90. J Med Chem 49: 817-828, 2006.

125. He H, Zatorska D, Kim J, Aguirre J, Llauger L, She Y, Wu N, Immormino RM, Gewirth DT and Chiosis G: Identification of potent water soluble purine scaffold inhibitors of the heat shock protein 90. J Med Chem 49: 381-390, 2006

126. Taldone T, Gozman A, Maharaj R and Chiosis G: Targeting Hsp90: small-molecule inhibitors and their clinical development Curr Opin Pharmacol 8: 370-374, 2008

127.Lundgren K, Zhang H, Brekken J, Huser N, Powell RE, Timple N, Busch DJ, Neely L, Sensintaffar JL, Yang YC, McKenzie A, Friedman J, Scannevin R, Kamal A, Hong K, Kasibhatla SR, Boehm MF and Burrows FJ: BIIB021, an orally available, fully synthetic small-molecule inhibitor of the heat shock protein Hsp90. Mol Cancer Ther 8: 921-929, 2009.

128. Yin X, Zhang H, Lundgren K, Wilson L, Burrows $\mathrm{F}$ and Shores CG: BIIB021, a novel Hsp90 inhibitor, sensitizes head and neck squamous cell carcinoma to radiotherapy. Int J Cancer 126: 1216-1225, 2010.
129.Zhang H, Neely L, Lundgren K, Yang YC, Lough R, Timple N and Burrows F: BIIB021, a synthetic Hsp90 inhibitor, has broad application against tumors with acquired multidrug resistance. Int J Cancer 126: 1226-1234, 2010

130. Elfiky A, Saif MW, Beeram M, Brien SO, Lammanna N, Castro JE, Woodworth J, Perea R, Storgard C and von Hoff DD: BIIB021, an oral, synthetic non-ansamycin Hsp90 inhibitor: phase I experience. J Clin Oncol 26: abs. 2503, 2008.

131. Rowlands MG, Newbatt YM, Prodromou C, Pearl LH, Workman P and Aherne W: High-throughput screening assay for inhibitors of heat-shock protein 90 ATPase activity. Anal Biochem 327: 176-183, 2004.

132. Cheung KM, Matthews TP, James K, Rowlands MG, Boxall KJ, Sharp SY, Maloney A, Roe SM, Prodromou C, Pearl LH, Aherne GW, McDonald E and Workman P: The identification, synthesis, protein crystal structure and in vitro biochemical evaluation of a new 3,4-diarylpyrazole class of Hsp90 inhibitors. Bioorg Med Chem Lett 15: 3338-3343, 2005

133. Kreusch A, Han S, Brinker A, Zhou V, Choi HS, He Y, Lesley SA, Caldwell J and Gu XJ: Crystal structures of human HSP90 alpha-complexed with dihydroxyphenylpyrazoles. Bioorg Med Chem Lett 15: 1475-1478, 2005.

134. Sharp SY, Boxall K, Rowlands M, Prodromou C, Roe SM, Maloney A, Powers M, Clarke PA, Box G, Sanderson S, Patterson L, Matthews TP, Cheung KM, Ball K, Hayes A, Raynaud F, Marais R, Pearl L, Eccles S, Aherne W, McDonald E and Workman P: In vitro biological characterization of a novel, synthetic diaryl pyrazole resorcinol class of heat shock protein 90 inhibitors. Cancer Res 67: 2206-2216, 2007.

135. Dymock BW, Barril X, Brough PA, Cansfield JE, Massey A, McDonald E, Hubbard RE, Surgenor A, Roughley SD, Webb P, Workman P, Wright L and Drysdale MJ: Novel, potent small molecule inhibitors of the molecular chaperone Hsp90 discovered through structure-based design. J Med Chem 48: 4212-4215, 2005.

136. Brough PA, Aherne W, Barril X, Borgognoni J, Boxall K, Cansfield JE, Cheung KM, Collins I, Davies NG, Drysdale MJ, Dymock B, Eccles SA, Finch H, Fink A, Hayes A, Howes R, Hubbard RE, James K, Jordan AM, Lockie A, Martins V, Massey A, Matthews TP, McDonald E, Northfield CJ, Pearl LH, Prodromou C, Ray S, Raynaud FI, Roughley SD, Sharp SY, Surgenor A, Walmsley DL, Webb P, Wood M, Workman P and Wright L: 4,5-Diarylisoxazole Hsp90 chaperone inhibitors: potential therapeutic agents for the treatment of cancer. J Med Chem 51: 196-218, 2008

137. Hammond LA, Denis L, Salman U, Jerabek P, Thomas CR Jr and Kuhn JG: Positron emission tomography (PET): expanding the horizons of oncology drug development. Invest New Drugs 21: 309-340, 2003

138. Chandarlapaty S, Sawai A, Ye Q, Scott A, Silinski M, Huang K, Fadden P, Partdrige J, Hall S, Steed P, Norton L, Rosen N and Solit DB: SNX2112, a synthetic heat shock protein 90 inhibitor, has potent antitumor activity against HER kinase dependent cancers. Clin Cancer Res 14: 240-248, 2008.

139. Okawa Y, Hideshima T, Steed P, Vallet S, Hall S, Huang K, Rice J, Barabasz A, Foley B, Ikeda H, Raje N, Kiziltepe T, Yasui H, Enatsu S and Anderson KC: SNX-2112, a selective Hsp90 inhibitor, potently inhibits tumor cell growth, angiogenesis, and osteoclastogenesis in multiple myeloma and other hematologic tumors by abrogating signaling via Akt and ERK. Blood 113: 846-855, 2009.

140. Jin L, Xiao CL, Lu CH, Xia M, Xing GW, Xiong S, Liu QY, Liu H, Li YC, Ge F, Wang QD, He QY and Wang YF: Transcriptomic and proteomic approach to studying SNX-2112induced K562 cells apoptosis and anti-leukemia activity in K562-NOD/SCID mice. FEBS Lett 583: 1859-1866, 2009

141.Lin TY, Bear M, Du Z, Foley KP, Ying W, Barsoum J and London C: The novel HSP90 inhibitor STA-9090 exhibits activity against kit-dependent and -independent malignant mast cell tumors. Exp Hematol 36: 1266-1277, 2008.

142. McCleese JK, Bear MD, Fossey SL, Mihalek RM, Foley KP, Ying W, Barsoum $\mathrm{J}$ and London CA: The novel HSP90 inhibitor STA-1474 exhibits biologic activity against osteosarcoma cell lines. Int J Cancer 125: 2792-2801, 2009. 